Abstracta Iranica Abstracta Iranica

Revue bibliographique pour le domaine irano-aryen

Volume 22 | 2001

Comptes rendus des publications de 1999

\title{
"Buddha Icon from Panjikent ", Silk Road Art and Archaeology, 5, (1997-8), pp. 297-305.
}

\section{Étienne de La Vaissière}

\section{(2) OpenEdition}

1 Journals

Édition électronique

URL : http://journals.openedition.org/abstractairanica/36277

DOI : 10.4000/abstractairanica.36277

ISSN : 1961-960X

\section{Éditeur :}

CNRS (UMR 7528 Mondes iraniens et indiens), Éditions de l'IFRI

\section{Édition imprimée}

Date de publication : 15 mai 2001

ISSN : 0240-8910

\section{Référence électronique}

Étienne de La Vaissière, « «Buddha Icon from Panjikent », Silk Road Art and Archaeology, 5, (1997-8), pp. 297-305. », Abstracta Iranica [En ligne], Volume 22 | 2001, document 99, mis en ligne le 15 février 2010, consulté le 10 octobre 2020. URL : http://journals.openedition.org/abstractairanica/36277 ; DOI : https://doi.org/10.4000/abstractairanica.36277

Ce document a été généré automatiquement le 10 octobre 2020.

Tous droits réservés 


\title{
« Buddha Icon from Panjikent », Silk Road Art and Archaeology, 5, (1997-8), pp. 297-305.
}

\author{
Étienne de La Vaissière
}

\begin{abstract}
Les AA. présentent un moule de terre cuite représentant le Bouddha trouvé hors contexte à Pendjikent en 1995. Ils le comparent avec l'unique autre représentation du Bouddha connue sur ce site, une peinture au dessus de la porte d'une salle de réception. Ils soulignent le caractère peu orthodoxe des représentations, influencées par l'iconographie mazdéenne sogdienne. Ces maladresses montrent que le bouddhisme était au fond mal connu dans la vallée du Zérafshan, même si certains tenaient à avoir une image du Bouddha, parmi d'autres dieux. Le témoignage de Xuanzang sur la faible pénétration du bouddhisme en Sogdiane proprement dite est ainsi confirmé.
\end{abstract}

\section{INDEX}

Thèmes : 3.1. Est de l'Iran

\section{AUTEURS}

ÉTIENNE DE LA VAISSIÈRE

ENS - Paris 